

\title{
Winston Churchill, the Morning Post and the End of the Imperial Romance.
}

\section{Brief Biography:}

Andrew Griffiths studied at the University of Exeter and teaches at Plymouth University and the Open University. His research addresses the relationship between New Imperialism, New Journalism and fiction in the late nineteenth century. He is currently working on a project which focuses on the role of the special correspondent at the heart of this relationship.

\begin{abstract}
:
Winston Churchill's Morning Post correspondence from Kitchener's 1898 Sudan expedition documents a shift in the practice and reportage of imperialism. Sensational New Journalism and aggressive New Imperialism had been locked in a mutually-supportive relationship. Special correspondents, including Churchill, emphasised the romance of empire. However, Churchill also looked forward with trepidation to a time when "there will be no more of these nice little expeditions $[\ldots]$ no more peerages for the generals, no more copy for the journalists." Kitchener's application of military technology produced a combination of tedium and horror which challenged correspondents. Churchill's Sudan correspondence records the end of Britain's imperial romance.
\end{abstract}




\section{Winston Churchill, the Morning Post and the End of the Imperial Romance.}

Perhaps the time will come when the supply will be exhausted and there will be no more royal freaks to conquer. In that gloomy period there will be no more of these nice little expeditions $[\ldots]$ no more medals for the soldiers, no more peerages for the generals, no more copy for the journalists. The good times will have passed away, and the most cynical philosopher will be forced to admit that though the world may not be much more prosperous it can scarcely be so merry. ${ }^{1}$

Winston Spencer Churchill wrote the above lament for a passing age on September 12, 1898, ten days after participating in the battle of Omdurman as both cavalry officer and Morning Post special correspondent. The idea that imperialism provided entertaining spectacle in the hands of enterprising journalists is conveyed with unusual directness. Both Churchill and his newspaper considered the reconquest of the Sudan as elements of a long-running romantic narrative. His employers at the Morning Post were explicit on this point: an anonymous article of September 5, 1898, printed while news of the victory at Omdurman was still filtering out, was entitled "The Romance of Khartoum". ${ }^{2}$ Churchill called Kitchener's campaign "the last Act in the great Drama of Khartoum."3 A rival correspondent, George Warrington Steevens of the Daily Mail, wrote of the "romance of the Sudan". 4 This was a long running theme. When General Gordon was sent on his ill-fated mission to Khartoum in 1884 , the Illustrated London News had proudly informed its readers that his achievements to date had been "more wonderful than are to be found in the wildest Oriental romance". ${ }^{5}$ However, the sense that Kitchener's campaign was the concluding chapter of the imperial romance was also strong. "The Romance of Khartoum" included the following passage: "But it has ceased. Gordon is avenged, and the tens of thousands of massacred creatures are avenged, and with gentle tenderness the fertile, fair Soudan will be won to civilisation." " A fin de siècle mood gripped the Morning Post journalist, just like Churchill: the good times of imperial 
romance were being swept aside by modernity.

This article has two aims. One is to reassert the significance of Churchill's early journalism, which has yet to receive the attention it deserves, through a critical reading of his war correspondence from the Sudan. This correspondence constitutes a perceptive record of a moment of significant but often unremarked change in Britain's discourse of empire. The second objective of this article is to argue that the representation of empire in the periodical press was irrevocably changed by the Sudan campaign and, more precisely, by the correspondence it produced. It is perhaps unsurprising that Churchill's political career has eclipsed his early journalism, which is addressed, if at all, as part of the foundation for his later success. Roy Jenkins, Douglas S. Russell and Richard Toye are among those who have, very usefully, commented on Churchill's writing in this manner. ${ }^{7}$ However, few scholars have approached Churchill's journalism as an object of study in its own right. Paul K. Alkon has treated of Churchill's visual imagination, Manfred Weidhorn has surveyed his long writing career, and Frederick Woods has both edited a useful volume of Churchill's war correspondence and written a monograph on Churchill as a writer. ${ }^{8}$ All these volumes are valuable and inform this study. However, few other winners of a Nobel Prize for literature can have attracted so little scholarly attention. Certainly, Churchill's writing had a greater impact on his contemporaries than on modern-day scholars. He developed his public profile through his popular journalism and was propelled to victory in the Oldham seat in the "khaki election" of 1900 by the enormous publicity generated by his accounts of capture and escape during the Boer War. Churchill's perceptive and prescient analysis of the effects of modernity on the imperial romance during the 1898 Sudan campaign should be of compelling interest to scholars of empire and the history of the periodical press alike.

The fourteen years intervening between Gordon's death in February 1885 and the recapture of Khartoum in September 1898 were significant in the history of imperial culture. A close relationship between the populist and sensational New Journalism and the aggressively expansionist New Imperialism had been established at least since the influential Pall Mall Gazette editor William 
Thomas Stead interviewed General Gordon in January 1884, commencing a (successful) campaign advocating his deployment to the Sudan. The ways in which this relationship transformed the relationship of the British public to their empire have been widely discussed. John M. MacKenzie has done much to highlight "the popular excitements generated by (or generating?) imperial expansion." John O. Springhall has pointed out that "[i]t was no accident that the 'little wars' of Empire $[\ldots]$ provided the most readily available source for magazine and newspaper editors of romantic adventure and heroism". ${ }^{10}$ Importantly Richard Fulton has argued that the 1898 Sudan campaign was nothing less than the core of a multimedia "Sudan Sensation", generated partly by a series of "virtually bloodless victories against overwhelming numerical odds" and partly by "the professional war correspondents' lionizing accounts of Kitchener and his gallant heroes". ${ }^{11}$ However, Churchill's Morning Post correspondence not only exposes fractures in the relationship between New Imperialism and New Journalism (especially concerning the control of the press and the representation of industrial warfare) but also implies that the imperial romance it generated was unsustainable.

By 1898 , the symbiosis of New Journalism and New Imperialism had established a new and important example of imperial masculinity: the special correspondent. Occupying a privileged position the special correspondents mediated between imperial frontier and metropolitan hearth. The British reading public experienced imperialism vicariously through their accounts. This privileged position enabled the most famous correspondents not only to report the news but also to make that news. The Daily News's Algernon Forbes, for example, is remembered for his ride through hostile territory carrying news of the British victory over the Zulus at Ulundi. Edmund Donovan, also working for the big-spending Daily News disappeared while covering Hicks Pasha's ill-fated Sudan expedition and unfounded rumours concerning his survival and subsequent adventures circulated long after his death. Henry Morton Stanley "found" Livingstone and traversed Africa on behalf of the New York Herald and the Daily Telegraph. Stefanie Markovits has accurately described the special correspondent as "a first person everyman of a narrator/hero". ${ }^{12}$ 
The nature of the special correspondent was already undergoing subtle changes by 1898 , however. A self-identified "'scion' of the ancient British aristocracy", Churchill was hardly an everyman figure. ${ }^{13}$ His adept exploitation of the imperial romance and the special correspondent persona was what gave him his mass appeal.

Churchill's correspondence was not so straightforwardly jingoistic as this might lead one to expect, however. Following a conventional interpretation of the work of the special correspondents, Fulton suggests that in the Sudan in 1898, "Every Special wrote in the adventure story discourse" while "the overwhelming tenor of the reports was triumphalism". He notes, in rightly critical tone, "the militaristic, patriotic, nationalistic blather of the professional war correspondents, whose careers depended on a campaigning army". ${ }^{14}$ No less a source than Rudyard Kipling supports this judgement. In his first novel, The Light That Failed, Kipling's protagonist berates a special correspondent (and his readers) with some venom: "you're sent out when a war begins, to minister to the blind, brutal, British public's bestial thirst for blood. They have no arenas now but they must have special correspondents". ${ }^{15}$ There is much truth in these remarks, but Churchill's correspondence complicates the picture. Ironic observations, like that about the end of "these nice little expeditions" and the associated medals, peerages and news stories, frequently call into question the role of the special correspondent and the conventional reading of their output. Warren Dockter's work on Churchill's relationship with Wilfrid Scawen Blunt, an outspoken critic of empire, notes the latter's approval of the tone adopted by Churchill in The River War. ${ }^{16}$ Even as Churchill exploited the mass appeal of the special correspondent persona he also undermined its foundations.

The New Journalism / New Imperialism compound had been a potent cultural force but, as Churchill's irony indicates, by the late 1890s the relationship between the two was degenerating. According to Alan J. Lee, the 1880s and 1890s saw the "increasing centralization of production and control" becoming "the leading characteristic of the national press", while Jurgen Habermas identified the period as that of the "great newspaper trusts". ${ }^{17}$ As a result of the mass success of the 
New Journalism, commercial and political concerns increasingly influenced the content of the newspapers. The technological advances without which, as Donald Read has noted, imperial expansion would have been neither practically nor conceptually possible were themselves eroding the romance of the New Imperialism, too. ${ }^{18}$ In G.R. Searle's assessment, steam and electricity had achieved nothing less than the "shrinkage of the world". ${ }^{19}$ Travel by railway and steamship lacked the romance of long treks through exotic territory, while magazine rifles, machine guns and quickfiring artillery diminished the adventurous potential of hostile encounters and the telegraph system enabled generals to control the news.

The battle outside Omdurman was Britain's moment of imperial hubris. Niall Ferguson’s hyperbolic description of the battle as "the acme of imperial overkill" is difficult to dispute in substance. ${ }^{20}$ In under three hours, the Mahdist forces lost between ten and eleven thousand men killed and approximately sixteen thousand wounded. The Anglo-Egyptian army, by contrast, suffered just forty-eight fatal casualties. ${ }^{21}$ The unromantic thoroughness of the victory, the result of the application of the most modern military technology, was intensely problematic for Churchill and his fellow special correspondents: Manfred Weidhorn observes that " $[\mathrm{t}]$ he sense of the horrors of war grows with each volume" of Churchill's early war writing, building towards the concession in The River War that "war is actually shabby". 22

The difficulty with which Churchill secured his place on the Nile expedition is indicative of the tensions which existed between New Journalism and New Imperialism by 1898. Kitchener objected to officers who, like Churchill, supplemented their income by writing for the newspapers. A sustained campaign of lobbying orchestrated by Churchill's mother, an illustrious socialite, was required to overcome this opposition. One supporter, Lady Jeune, sent a telegram to Kitchener which read simply "Hope you will take Churchill. Guarantee he won't write." ${ }^{23}$ Intercessions on 
Churchill's behalf from the Prime Minister, Lord Salisbury and the British agent in Egypt, Lord Cromer, were required before he received a post. Even then, the appointment was accompanied by War Office stipulation that in case of death or injury "no charge of any kind will fall on British Army funds". ${ }^{24}$ Lady Jeune's guarantee was an unfortunate one: before leaving London, Churchill had arranged with the Morning Post a fee of $£ 15$ per column for his correspondence. ${ }^{25}$ Kitchener, however, placed further obstacles in the way of journalists. He allowed only one correspondent, H.W. Gwynne, "the outstanding Reuter correspondent of the period", to travel at the front of the advance and to make use of military telegraph facilities. ${ }^{26}$ In the important New Journalism / New Imperialism relationship, censorship was replacing symbiosis.

The lack of access to the telegraph posed a serious problem for Churchill. The telegraph had been indispensable to the rise of the New Journalism and the emergence of the celebrity special correspondent. In 1886, Stead had proclaimed that "[t]he world has shrunk perceptibly under the touch of Stephenson and Faraday, of Hoe and of Edison". ${ }^{27}$ Algernon Forbes proudly recalled the occasion on which, thanks to undersea cables and time differences, he sent a telegram half-way around the world "in two hours less than no time at all", while Churchill himself acknowledged that "it is impossible not to feel a glow of confidence in the power of science which can thus link the most desolate regions of the earth with its greatest city and keep the modern pioneer ever within hail of home." ${ }^{28}$ Ever sensitive to change, Churchill found this stifling as well as inspiring: "One could not, of course, escape the ordinary telegraph. Its long coils wrapped around one even then."29 His employers at the Morning Post put the case rather differently, promoting their man:

The letter from our Special Correspondent with the advancing Anglo-Egyptian Force which appears elsewhere opens up quite an unexpected vista of progress. It is dated a fortnight back, but in effect, the information given in it is later than any given by telegrams, which have doubtless been subjected to the Censorship[.] ${ }^{30}$

This was precisely the reason Kitchener restricted access to the telegraph: doing so allowed him to manage the flow of information. The success of such measures was debatable: Richard Toye points 
out that Churchill was just one of "a whole pack of journalists". ${ }^{31}$ Nevertheless, these restrictions and the tone of the letter quoted above indicate a growing tension between the military and the press which would culminate in personal conflict between Kitchener and Lord Northcliffe in 1915. ${ }^{32}$

Churchill skilfully made the best of the restrictions under which he had to work. Fearful of the possibility of recall if he were identified as the author of the Morning Post letters, he introduced each as though it were a private letter passed to the newspaper by his correspondent. The first begins thus: "You would rightly call me faithless, my dear ..., if I were to make no effort to carry out my promise to give you some account of the features and the fortunes of the war on the Nile." 33 The mode of address had the additional benefit of fostering the illusion of direct personal engagement between correspondent and reader: that personal mediation was characteristic of the work of the special correspondent. Frederick Woods has pointed out that Churchill's desire for publicity conflicted with the need for anonymity. ${ }^{34}$ In a letter to a friend, Churchill feigned outrage at the publication of his letters at the same time as advertising his authorship of them: "If you look in the Morning Post it is possible that you will see that one of my friends has committed and continues to commit an unpardonable breach of confidence by publishing letters of mine. Don't give away the pious fraud as I don't want to be recalled." 35

The pious fraud was a matter of style, too. Churchill thought it "a most amusing conceit" which "from a literary point of view added to the elegance of the letters" ${ }^{36}$ G.W. Steevens, the Daily Mail special correspondent had found the idea "most fresh and original". ${ }^{37}$ Style was important to Churchill. He intended the letters to be "foundations and [...] scaffolding" for a book on the war. ${ }^{38}$ Churchill aimed to entertain his readers. His first letter proclaimed that "I shall try in this and following letters to paint you a picture of the war, and shall hope to raise in your mind a lively impression of the scenes and characters of the last act in the great drama of Khartoum." ${ }^{39} \mathrm{He}$ made a virtue of avoiding too much tedious detail-“you would hardly thank me for copying out the pages of a timetable"-and offered plenty of "colour" in his "picture of war" ${ }^{40}$ His style was very much of that of the New Journalism and the late-Victorian special correspondent: the highly 
personal format, visual description, drama and fast narrative were absolutely characteristic of the genre. Woods describes Churchill's prose as "economical, spare, sinewy, fast". ${ }^{41}$ The practice of imperialism was conceived as an adventure story in real time. It is no coincidence that Churchill had sent fan-mail to Henry Rider Haggard as a boy, or that he referred to his novels in his correspondence. ${ }^{42}$ This is precisely the style which Fulton calls "the adventure story discourse" and which would be called into question by the events of the campaign.

After Omdurman, no longer fearing recall, Churchill took steps to ensure that he was recognised as the Morning Post's correspondent. He informed his mother that "There need be no secret about my having written the letters" and expressed his hope in a letter to a military friend that he had recognised his "handiwork" in the Morning Post. ${ }^{43}$ Churchill signs off at the end of the final letter with a typically self-promoting flourish:

Since in these letters I have tried to write only what is fair and true, and because no man should write that of which he is either ashamed or afraid, I shall venture in conclusion to subscribe myself-

Yours truly,

\section{WINSTON SPENCER CHURCHILL ${ }^{44}$}

The block capitals emphasise the brashness of Churchill's self-promotion and the potent masculinity of the writer. This impression is only reinforced by the fact that, as Russell has pointed out, "the identity of the author was [already] known to many", rendering the gesture primarily theatrical. ${ }^{45}$ Such brazen self-dramatization is typical of the journalism produced by special correspondents, who (according to a typical description penned by an anonymous Leisure Hour correspondent) were expected to be "romantic and picturesque" figures. ${ }^{46}$

By contrast, the official Reuters telegrams have the timetable-like quality Churchill sought to avoid. A typical Reuters dispatch (published in The Times) contained the following information:

General Wauchope's British Brigade [...] is thoroughly acclimatised. [...] Of 3,600 men under 100 are in the hospital. The only sickness at any time prevalent has been a 
mild form of enteric fever. There has been a remarkable absence of dysentery. The men are kept in hard condition by route-marching in the desert twice weekly. [...] Practically all the officers have returned from leave.

\section{$[\ldots]$}

All the steamers from the Dongola reach have passed Abu Hamed and are on their way here. ${ }^{47}$

The clipped style of the official agency-supplied news is the antithesis of the special correspondent's personal, sensational, literary style. Former correspondent and prolific writer of adventure fiction George Alfred Henty listed the "gift of vivid description" among the essential qualifications of a special correspondent. ${ }^{48}$ Evidently such gifts were not among the essential qualities of the official news-agency dispatch writer. In an exchange characteristic of the Sudan campaign, information was substituted for romance.

As the Reuter's telegram indicates, transport and logistics were central to the campaign. Churchill observed that " $[\mathrm{t}]$ he versatile and ubiquitous Cook had undertaken these arrangements, as his name on everything clearly showed." 49 This was a matter of ironic pride to Churchill. "You may be amused", he wrote, "by the reflection that the great river has befriended all ages and with an impartial smile has borne the stately barges of the Pharaohs and the unpretentious stern wheel steamers of Messrs Cook and Sons (Egypt) (Limited). It has seen war with the ballista and the short Roman sword, and is now witnessing the military employment of 6in quickfiring guns and lyddite shells. [...] It will presently carry this letter to you. ${ }^{, 50}$ The romantic past has been supplanted by a utilitarian present. Churchill's description merges time and space, emphasising change. Nothing illustrates the convergence of commercial interests, imperialism and journalism better than the example of a tour company carrying soldiers up the Nile and news reports back down the river.

The means of transport most important to the successful prosecution of the campaign, however, was the railway. The Daily Mail's Steevens described the Sudan Military Railway as "the deadliest weapon that Britain has ever used against Mahdism." ${ }^{51}$ The railway was constructed as a 
faster and more reliable alternative to carrying supplies up the Nile, which was impassable when the waters were too high. For Churchill, the Sudan Military Railway represented all that was dynamic and progressive in Victorian military engineering: "The railway is the youngest in the world. It has grown faster than iron rails have ever been laid before: 'nearly a mile and a quarter a day,' say those who shared the labour and the credit of its construction." 52 The impact of the railway, like the romance of the Sudan, was recognised by several of the correspondents and writers who addressed the campaign. In Churchill's opinion "[f]ighting the Dervishes was primarily a matter of transport" - and this was hardly the stuff of romance. ${ }^{53}$ Churchill's description of the depot town Wadi Halfa reinforces the point: "From the growing workshops at Wady [sic] Halfa the continual clatter and clang of hammers and the black smoke of manufacture rose to the African sky. The malodorous incense of civilisation was offered to the startled gods of Egypt." ${ }^{54}$ The role of modern technology in defeating Mahdism and sweeping aside romance is absolutely clear.

The nature of the hero of Empire was changed, too. Of Kitchener, Steevens memorably suggested that "You feel that he ought to be patented and shown with pride at the Paris International Exhibition. British Empire: Exhibit No. I., hors concours, the Sudan Machine." 55 The days of messianic, eccentric figures like General Gordon were over, to be replaced with cold calculation and ruthlessness. The general was no longer the dashing figure of popular romance but a consummate manager, managing, amongst other things, the reports of his own actions. The new military hero was a hero of and a hero for modernity.

Churchill was sensitive to all these changes. His first Morning Post article details the tedium of military travel: "ever a long and wearying affair." "The journey from Cairo to the Atbara camp divides itself naturally into four stages," wrote a bored and weary Churchill, "through all of which the troops must toil, but through which I do not intend to tediously drag you. You shall fly airily along the miles of road, rail, and river, and shall pause merely where there is something to look at or something to discuss." ${ }^{57}$ Travel involves tedium, not exploration or sensation. Of poor conditions 
for the troops in transit, Churchill simply observes, "I know you care nothing for such matters, and would not sympathise were I to dilate upon them. ${ }^{" 58}$ Given the origins of war reporting in the Crimea, where W.H. Russell (to whom Woods favourably compares Churchill) did so much to bring inadequate logistical arrangements to the attention of the public, this comment is doubly significant. ${ }^{59}$ The jaded quality of Churchill's writing matched the jaded sensibility of his readers.

The letter also alludes to another difficulty. Unprecedented numbers of people were familiar with regions beyond Britain's shores from personal experience, or via print sources. As Churchill complained, "I am in the domain of Baedeker, and I will not do him or you an unkindness by transcribing his words nor by poaching on his preserves. Besides, surely you have 'done' the Nile yourself? Everyone 'does' it nowadays: you must not be eccentric." ${ }^{\prime 60}$ The temple at Luxor becomes an emblem of Churchill's difficulty. As if to underscore the link between fiction and correspondence, Churchill notes that the temple reminds him of Rider Haggard's Cleopatra ("perhaps the most popular book on Egyptology on the market") before explaining that, far from being a place of mystery and priestly power, "[i]t is $[\ldots]$ a favourite place of tourists to be photographed in. The science and triumph of the living century is displayed in vivid contrast with the art and repose of that long dead." ${ }^{61}$ Increased accessibility and new modes of representation deny Churchill the chance to offer sensation. "But Baedeker pricks my conscience", concludes Churchill, "I must write no more about Luxor, for is it not appropriately described in 'Route B, Cairo to Aswan'?"62

If tedium, tourism, telegraphy and photography presented serious obstacles for the correspondent to negotiate on the advance, the destination would prove still more challenging. The battle outside Omdurman brought home with clarity to Victorian readers a fresh consciousness of the destructive nature of progress. The horrific effects of military technology on the human body presented new challenges to the correspondent: romance had been replaced by machinery in shocking ways. The symbiosis between New Journalism and New Imperialism was jeopardised by the very technologies which had permitted it. 
Having recorded his journey south with frequent reference to transport and communications technology, Churchill displayed the same eye for technical progress on the battlefield. His soldierly enthusiasm for new means of waging war is at times cold-blooded and calculating: a Nietzschean celebration of the will to power. Churchill's commentary on the Mahdist army moving into effective range is a clear example of his attempts to discover an aesthetics of violence:

I was but three hundred yards away, and with excellent glasses could almost see the faces of the dervishes who met the fearful fire. About twenty shells struck them in the first minute. Some burst high in the air, others exactly in their faces. Others again plunged into the sand and exploding, dashed clouds of red dust, splinters and bullets amid their ranks. ${ }^{63}$

Precision and exactness characterise the violence inflicted by artillery fire. Seeing the intersection of modern technology with the human body appears exhilarating. The colours, textures and dynamics of the image Churchill presents have a kind of beauty. The human body fades into the background. The faces at which the shells burst are not quite visible. Joanna Bourke has discussed the contradictory phenomenon whereby soldiers "maintain[ed] an emotional distance from their victims $[\ldots]$ through the application of (and almost exclusive focus upon) technology" yet also “insisted upon emotional relationships and responsibility". ${ }^{64}$ Although Bourke's work primarily addresses twentieth-century conflicts, the combination of distancing through a focus on technology with a desire for personal engagement is evident in Churchill's prose.

Bourke also points out that, once complete, the business of killing tends to be "interpreted, elaborated, restructured" in the imagination. ${ }^{65}$ Such a re-imagining of violent experience for consumption at home was an integral part of the war correspondent's task. This observation goes some way to explaining a symphonic quality evident in Churchill's dispatch. The descriptions of 
shellfire quoted above are dynamic and urgent. Marching men and regular artillery fire establish rhythm. Long moments of tension build to an inevitable crescendo:

The ranges were known. It was a matter of machinery. The more distant cannonade passed unnoticed as the mind concentrated on the impending horror. I could see it coming. It was a matter of seconds and then swift destruction would rush on these brave men. ${ }^{66}$

Short, staccato sentences give the impression of motion. The technical data replace any humane consideration, and function as their own validation. For an army capable of projecting power into the least accessible regions morality is a secondary consideration, yet Churchill still attempts to humanise the "brave men" advancing under fire. As a correspondent Churchill was confronting all the same problems as the modernists of the coming decades. The resultant discourse differs profoundly from the romantic 'adventure story discourse' previously favoured by special correspondents.

David Harvey outlines the argument that in the late nineteenth century, and particularly after Nietzsche, a new aestheticism guided Western culture. To the degree that Nietzsche had led the way in placing aesthetics above science, rationality, and politics, so the exploration of aesthetic experience-"beyond good and evil"-became a powerful means to establish a new mythology as to what the eternal and the immutable might be about in the midst of all the ephemerality, fragmentation, and patent chaos of modern life. ${ }^{67}$ In Harvey's analysis, the philosophies of Enlightenment had produced by the late nineteenth century a powerful tendency to conceive society in the terms of the battlefield: ephemeral, fragmentary, chaotic. This chaos of "creative destruction" rendered traditional teleologies and philosophies irrelevant. Nietzsche perceived this process in terms which would not seem out of place in Adorno and Horkheimer's Dialectic of Enlightenment: "Is the nineteenth century," he asked, "especially in its closing decades, not merely a strengthened, brutalized eighteenth century, that is to say a century of decadence?" ${ }^{98}$ Representing such decadence constituted a further challenge in Nietzsche's view: "We have already grown beyond 
whatever we have words for." ${ }^{69}$ Omdurman was not simply a neat and tidy ending to the incomplete narrative of General Gordon: it destroyed the possibility of such a romantic narrative. The challenge for the correspondent of the decadent, chaotic and brutal fin de siècle is to organise the fragments of experience into a simple narrative for popular consumption.

The chaotic complexity of warfare meant that any such organisation was fraught with difficulties. Churchill's technical and symphonic conception of the battlefield was a means of conceiving it as a unified form in space and time. Paul K. Alkon has argued that Churchill's visual description served the same purpose. As Alkon notes, Churchill likened the advancing Mahdist army to "the old representations of the Crusaders in the Bayeux tapestry". ${ }^{70}$ The need for a familiar image was clearly greater than the desire for accuracy. The annihilation of space by modern weapons continually threatens the unity of Churchill's account, however, detaching him from the conflict: "Above the heads of the moving masses shells began to burst, dotting the air above with smoke balls and the ground with bodies. But they were nearly two miles away, and the distance rendered me unsympathetic." ${ }^{71}$ Churchill's lack of sympathy at two miles distance matches the detachment of his readers, thousands of miles distant.

Churchill emphasises this at the end of the letter: "The wounded were sent with a small escort towards the river and hospitals. Then we remounted, and I observed, looking at my watch, that it was half-past nine - only breakfast time, that is to say, in distant, comfortable England."72 The battle has been a brief interlude in Churchill's life, and a still smaller intervention in his readers' lives. As David Harvey comments: “The map of domination of the world's spaces changed out of all recognition between 1850 and 1914. Yet it was possible, given the flow of information and new techniques of representation, to sample a wide range of simultaneous imperial adventures and conflicts with a mere glance at the morning newspaper." ${ }^{, 73}$ Churchill's link in time between the Sudan and England brings home the interconnectedness of the two. Distance remains, but must be understood as the difference of experience between the breakfast table and the battlefield rather than physical distance. 
The collapse of space and time into a matrix of mechanised destruction on the battlefield which defies analysis or humanitarian comment challenged correspondents familiar with a mode of reportage which involved maximising the physical distance between home and imperial frontier and minimising the conceptual distance between the explorer or soldier and the reader. The established rhetoric of the special correspondent was no longer appropriate to the task. The readers of Forbes, Henty, Kipling, or Haggard had been able to participate vicariously in real or imagined adventures and travels. The idea of such participation at Omdurman was profoundly problematic.

Only one portion of the battle offered the kind of personal engagement and derring-do which special correspondents had previously thrived on. The charge of the $21^{\text {st }}$ Lancers, the unit to which Churchill was attached, into a numerically superior mass of Mahdist warriors was subsequently identified as an error. Nevertheless, it was this charge which most fully caught the public imagination. If mechanised slaughter was too morally dubious to be uncomplicatedly celebrated, the charge of a full regiment of cavalry offered correspondent and reader the chance to engage personally in battle. Churchill rode in the charge, and his report was widely republished. It was the only part of his correspondence to reappear outside the columns of the Morning Post. ${ }^{74}$ His account of the charge is worth examining in some detail. Churchill describes how "the two living walls crashed together with a mighty collision":

The Dervishes stood their ground manfully. They tried to hamstring the horses. They fired their rifles pressing their muzzles into the very bodies of their opponents. They cut bridle-reins and stirrup-leathers. They would not budge till they were knocked over. They stabbed and hacked with cool pertinacity. [...] The regiment broke completely through the line everywhere, leaving sixty Dervishes dead and many wounded in their track. [...] Riderless horses galloped across the plain. Men clinging onto their saddles, lurched hopelessly about, covered with blood from perhaps a dozen wounds. Horses streaming from tremendous gashes limped and staggered with 
their riders. In one hundred and twenty-five seconds five officers, sixty-six men, and one hundred and nineteen horses out of less than three hundred had been killed or wounded..$^{75}$

The close physicality of this combat stands in stark contrast to the scientific and arbitrary destructiveness of artillery and long-range small arms fire. The short sentences again convey the speed of the encounter, and the details of stabbing and hacking, of point-blank firing and desperate riding appeal to readers, offering something familiar to those who had read accounts of previous imperial adventures. The terrifying impact of horses and men may be clearly imagined. This short passage of descriptive writing has all that successful Victorian war correspondence could offer. However, even this representation is inflected by the presence of modern technology.

Alkon draws the reader's attention to the edited account of the charge given in The River War, and to one statement in particular: "The whole scene flickered exactly like a cinematograph picture; and besides, I remember no sound. The event seemed to pass in absolute silence." ${ }^{, 76}$ This, like the sense of battle as symphony, painting, or tapestry remarked elsewhere, constitutes an attempt to encapsulate the experience of warfare in a manageable image. Alkon is quite right to remark Churchill's assumption of his readers" "familiarity with cinematograph screenings". ${ }^{77}$ Still a novelty in 1898 , the motion picture camera would transform the profession of the special correspondent. As Simon Popple and Joe Kember have suggested, motion pictures provided "a new technical iconography", replacing traditional correspondence. ${ }^{78}$ Once again, the Omdurman campaign was a turning point. Churchill commented on the presence of "war correspondents equipped with ice machines, typewriters, cameras, and even cinematographs." ${ }^{~ 79}$ At Omdurman, Frederic Villiers claimed to have attempted to record film footage from the deck of a gunboat, until the recoil of the vessel's guns knocked over his apparatus. ${ }^{80}$ John Montagu Benett-Stanford had some success in film-making during the campaign. ${ }^{81}$ Correspondence was to be transformed (and in some ways superseded) by new ways of seeing and recording the world. The prose of the leading correspondents had been commended for its visual or cinematic quality. Now the consumer of news 
could get the real thing. As detailed in the work of John Barnes, film was widely used during the Boer War, notably by Benett-Stanford. ${ }^{82}$ Churchill's narrative of the charge of the lancers, conceived as a film scene, highlights the changes in progress.

Churchill added to his original narrative separate accounts of individual acts of bravery. While the Morning Post reserved the main description of the charge for its own pages, Churchill's reflections on the charge appeared in a range of national and regional newspapers, as did his account of the bravery of one Private Byrne, who despite being wounded rescued an officer from the Dervish infantry. These articles appeared widely, reaching The Belfast News-Letter, the Glasgow Herald and the Manchester Times. After a short delay, Churchill's words on Private Byrne even appeared alongside a report on "Fowl Stealing at Dawlish" in Trewman's Exeter Flying Post, or Plymouth and Cornish Advertiser ${ }^{83}$ If the public enthusiasm for modern warfare was limited, the market for individual heroism was as buoyant as ever. It was Churchill's good fortune to be the only correspondent involved in the charge. Kitchener's clinical conduct of the reconquest of the Sudan using the very latest in military technology had otherwise denied him the chance to offer the kind of personal interest which made good correspondence.

The charge provided opportunity for criticism of the conduct of the battle. While otherwise British troops took few casualties, the $21^{\text {st }}$ Lancers, in Churchill's own estimation, lost $25 \%$ of their men in the first charge alone, without contributing significantly to the conclusion of the battle. For Churchill however, the charge was nothing less than an affirmation of racial superiority:

We may now discern the reason why this charge - which did not greatly influence the fortunes of the battle-was of perhaps as great value to the Empire as the victory itself. [...] Perhaps there have been moments when we have doubted whether those qualities which enabled us to conquer are unimpaired; whether the blood of the race circulates as healthy and as free as in days gone by. ${ }^{84}$

Questions of blood and racial vitality have been raised by the very industrialisation which had vested such power in the British Empire. Churchill had feared the "degeneration and decay" of the 
empire. ${ }^{85}$ As Toye, Russell and others have noted, he was impressed by the charge precisely because it was not technological: it was simply the impact of men and horses and brute force, with weapons not fundamentally changed in centuries. ${ }^{86}$ The soldiers followed their officers to death with "the discipline of a pack of hounds, not that of a flock of sheep" ${ }^{87}$ This recalls the argument advanced by John Kucich that acts of willing sacrifice were the foundations of the British Empire. ${ }^{88}$ The soldiers, to Churchill's relief had not degenerated. Churchill's focus on the charge demonstrated the depth of his concern.

One further aspect of the battle remained to be reported after the charge of cavalry was over and the infantry had pacified Omdurman. The battlefield itself had become a tableau of all the violence of modern industry. "We passed over a corner of the field of fire," remarked Steevens, "and saw for certain what slaughter we had done. The bodies were not in heaps - bodies hardly ever are; but they spread evenly over acres and acres. ${ }^{" 89}$ Even the typically jingoistic G.A. Henty conceded in his novel With Kitchener in the Soudan that " $[\mathrm{t}]$ he field presented a terrible appearance, being thickly dotted with dead". ${ }^{90}$ Churchill was well aware of the grisly fascination an account of the state of the field would provoke. At the conclusion of the two letters published describing events after the battle, he promises a description "of the scenes which the field of battle displayed." He also promises a level of censorship, "as the taste for realism is one which should not be greatly encouraged" for "[t]he desire to hear about dreadful things and the desire to see them are, after all, akin. Who is to say that the desire to do them is not also in the relationship?"91 Omdurman was not appropriate material for realistic description, in Churchill's view. Indeed, he suggests that "any attempt I make to depict the horrible sights [...] will differ from the reality as a shadow does from the substance." 92 Churchill gives the impression that the sights are shocking to him: "In a space not exceeding a hundred yards square more than four hundred corpses lay festering. Can you imagine the postures in which man, once created in the image of his Maker had been twisted? Do not try [...]"93 Churchill's own horror is still shocking to the reader. Without describing in detail the attitudes of the Dervish dead he conveys a vivid impression of the oppressive atmosphere of the 
field.

The treatment of the dead was an important subject for Churchill: "When the soldier of a civilised power is killed in action his limbs are composed and his body is borne by friendly arms reverently to the grave. [...] But there was nothing dulce et decorum about the Dervish dead. [...] The conviction was borne in on me that their claim beyond the grave in respect of a valiant death was as good as that which any of our countrymen could make." ${ }^{94}$ It is no coincidence that Wilfred Owen would reject the same Latin formulation in his famous poem of 1917. Omdurman had ushered in a new kind of warfare, in which the dead would not be buried with ritual or respect. With specific reference to the destruction of men's bodies, Joanna Bourke has argued that "nothing in British history [...] was adequate preparation for the physical devastation of the First World War."95 However, the field at Omdurman prefigured the fields of Flanders and Picardy on many levels.

Churchill wrote that dead Dervish soldiers had been "destroyed, not conquered by machinery." 96 The field challenged Churchill's belief in the cause for which he had been fighting, calling into question deeply-held beliefs about masculinity and honour:

I have writ somewhat in these letters to you of vengeance and of the paying of a debt. It has been said that the gods forbade vengeance to mankind because they reserved for themselves so delicious and intoxicating a drink, and it may well be that vengeance is sweet. But one should not drain the cup quite to the bottom. The dregs are sometimes filthy tasting. In any case a surfeit should be avoided. ${ }^{97}$

Churchill later reflected that war "has been completely spoilt. It is all the fault of democracy and science. [...] From the moment democracy was admitted to, or rather forced itself upon the battlefield, War ceased to be a gentleman's game."98

Churchill was not the only critical commentator. While many celebrated "the Great Vengeance" 
with Stead's Pall Mall Gazette, or reflected with The Times that, though "[t]he sentiment may shock a handful of superior persons", vengeance "is based upon a wholesome instinct", others were less convinced. ${ }^{99}$ For Steevens it was all "a most appalling slaughter". An anonymous correspondent writing to Saturday Review wondered "to what extent human life may be justifiably sacrificed to spread the blessings of civilisation[?]" and concluded with the reflection that, "Looked at dispassionately, what is it but scientific slaughter on a gigantic scale?". ${ }^{100}$ Long-standing critic of imperialism, Wilfred Scawen Blunt published a powerful condemnation of the battle in The Woman's Signal:

I will not hesitate longer to say that a massacre so gigantic in its proportions and so little justified by any circumstances of necessity or self-defence, was never committed by a modern nation since wars began; nor do I doubt that as such it will ultimately be known to our sons. Moreover, I venture to affirm that its unquestioning acceptance and justification by our whole English nation marks the deed as a turning point in our national character, which separates our way of looking at things, right or wrong, from that of our fathers. ${ }^{101}$

Blunt was not quite right to call attention to the unquestioning acceptance and justification of the battle: even the most triumphant editorial in The Times had to acknowledge that there were dissenters from the narrative of vengeance. Churchill and Steevens had voiced doubts. Blunt, who would soon embrace leading figures in modernist writing, was absolutely right to suggest that Omdurman might be viewed as a turning-point.

Churchill's correspondence from Omdurman recorded the beginning of the end for the imperial romance. Neither realistic nor romantic reportage could present the actualities of modern imperialism. The presence of motion-picture cameras had already impacted on Churchill's descriptive imagery and would subsequently alter irreversibly the reportage of warfare. Kitchener's use of the Reuters press agency to control the flow of information was a taste of things to come: a fully-fledged censorship would operate under his command during the Boer War. The kind of war 
reporting Evelyn Waugh memorably satirised in his 1938 novel Scoop, officially obstructed at every turn, began to emerge in the deserts of the Sudan. Kitchener's conduct of the war in South Africa would be equally ruthless, too. The concentration camps established in South Africa had no place in any imperial romance and provided a fresh focus for many of the critical voices which had been raised in response to Omdurman. Equally relevant is the fact that the generation of officers present at Omdurman would supply the senior commanders of the First World War. Kitchener would serve as Secretary of State for War, once again placing restrictions on the press. Churchill (who would, of course, be appointed First Lord of the Admiralty) recalled the future Admiral Beatty throwing him a magnum of champagne from the deck of a gunboat on the Nile. ${ }^{102}$ Major von Tiedemann, German military attaché with the Anglo-Egyptian force, was to report back to the Kaiser and the high command on the effectiveness of machine-gun fire. ${ }^{103}$ Churchill's prediction that there would be "no more of these nice little expeditions [...] no more medals for the soldiers, no more peerages for the generals, no more copy for the journalists" was not quite true in substance. ${ }^{104}$ At the very least, however, Churchill's correspondence from the Sudan describes the beginning of the end for the imperial romance.

\footnotetext{
$1 \quad$ Winston Churchill, "The Entry into Omdurman," Morning Post, September 29, 1898: 6.

2 Morning Post, "The Romance of Khartoum," September 5, 1898: 6.

$3 \quad$ Churchill, “The Soudan Campaign,” Morning Post, August 31, 1898: 5.

4 Steevens, With Kitchener to Khartoum, 1.

$5 \quad$ Illustrated London News "London," 74.

6 Morning Post, "The Romance of Khartoum," 6.

7 Roy Jenkins, Churchill; Russell, Winston Churchill: Soldier; Richard Toye, Churchill's Empire: The World that Made Him and the World He Made.

8 Weidhorn, Sword and Pen: A Survey of the Writings of Winston Churchill; Woods, ed., Winston S. Churchill: War Correspondent, 1895-1900 and Artillery of Words: The Writings of Sir Winston Churchill; Alkon, Winston Churchill's Visual Imagination.

9 MacKenzie, ed., Imperialism and Popular Culture, 1.

10 Springhall, “'Up Guards and At them!': British imperialism and popular art, 1880-1914,” 49.

11 Fulton, "The Sudan Sensation of 1898," 38.

12 Markovits, "Rushing Into Print: 'Participatory Journalism' During the Crimean War," 566.

13 Churchill, My Early Life: A Roving Commission, 223.

$14 \quad$ Fulton 42, 59.

15 Kipling, The Light That Failed, 70.
} 
17 Lee, The Origins of the Popular Press in England, 1855-1914, 128; Habermas, The Structural Transformation of the Public Sphere, 186.

18 Read, England, 1868-1914: The Age of Urban Democracy, 189.

19 Searle, A New England? Peace and War, 1886-1918, 616.

20 Ferguson, Empire: How Britain Made the Modern World, 267.

21 Pakenham gives figures of 10,800 dead and 16,000 wounded. Pakenham, The Scramble for Africa, 546.

22 Weidhorn 24-5.

23 Jeune, Susan, Baroness St Helier, Lady Jeune to Sir H. Kitchener, July 1898, 949.

24 Jenkins, Churchill, 39.

25 Jenkins, 19.

26 Read, The Power of News: The History of Reuters, 1848-1989, 106.

27 Stead, "Government by Journalism," 653.

28 Forbes, "A War Correspondent's Reminiscences," The Nineteenth Century and After: A Monthly Review, 424425; Churchill, "The War on the Nile," Morning Post, September 2, 1898: 5.

29 Churchill, My Early Life, 184.

30 Morning Post "London," 4.

31 Toye, 52.

32 Wilson, The Myriad Faces of War: Britain and the Great War, 1914-18, 202. Churchill, "The Soudan Campaign," Morning Post, August 31, 1898: 5.

Woods xxii.

Churchill, WSC to Captain Aylmer Haldane, August 11, 1898, 964.

Churchill, WSC to Lady Randolph, September 17, 1898, 980.

Churchill, WSC to Lady Randolph, September 17, 1898, 981.

Churchill, WSC to Lady Randolph, August 10, 1898, 961.

Churchill, "The Soudan Campaign," Morning Post, August 31, 1898: 5.

Churchill, "The Soudan Campaign," Morning Post, August 31, 1898: 5.

Woods, Artillery of Words, 41.

Haggard, The Days of My Life, 275; Churchill, “The Soudan Campaign,” Morning Post August 31, 1898: 5.

44 Churchill, "The Soudan Campaign," Morning Post, October 13, 1898: 5.

45 Russell, 202.

46 Leisure Hour, "How the Newspaper is Made," 39.

Henty, "The Life of a Special Correspondent," 570.

Churchill, "The Soudan Campaign," Morning Post, August 31, 1898: 5.

Churchill, "The Soudan Campaign," Morning Post, August 31, 1898: 5.

Steevens, 22.

Churchill, "The War on the Nile," Morning Post, September 24, 1898: 6.

Churchill, The River War, 163.

Churchill, The River War, 172.

Steevens, 46.

Churchill, "The Soudan Campaign," Morning Post, August 31, 1898: 5.

Churchill, “The Soudan Campaign," Morning Post, August 31, 1898: 5.

Churchill, "The Soudan Campaign," Morning Post, August 31, 1898: 5.

Woods, Artillery of Words, 51, 54.

Churchill, "The Soudan Campaign," Morning Post, August 31, 1898: 5.

Churchill, "The Soudan Campaign," Morning Post, August 31, 1898: 5.

Churchill, "The Soudan Campaign," Morning Post, August 31, 1898: 5.

Churchill, "The Battle of Omdurman," Morning Post, September 29, 1898: 5

Bourke, An Intimate History of Killing, 5, 7.

Bourke, An Intimate History of Killing, 11.

Churchill, "The Battle of Omdurman," Morning Post, September 29, 1898: 5.

Harvey, The Condition of Postmodernity: An Enquiry into the Origins of Cultural Change, 18.

Nietzsche, Twilight of the Idols and The Anti-Christ, 115.

Nietzsche, 94.

Alkon, 99. Churchill subsequently corrected his error.

Churchill, "The Battle of Omdurman," Morning Post, September 29, 1898: 5.

Churchill, "The Battle of Omdurman," Morning Post, September 29, 1898: 5.

Harvey, 264.

That is, before the publication of The River War. 
Churchill, "The Battle of Omdurman,” Morning Post, September 29, 1898: 5.

Alkon, 143.

Alkon, 143.

Kember and Popple, Early Cinema: From Factory Gate to Dream Factory, 40.

Alkon, 143.

Springhall, 58-9.

Fulton, 38.

Barnes, The Beginnings of Cinema in England: 1894-1914, 52-57.

[Churchill] “A Brave Lancer," Trewman's Exeter Flying Post or Plymouth and Cornish Advertiser, October 15, 1898: 3 .

84 Churchill, "Reflections on the Cavalry Charge," Morning Post, October 7, 1898: 5.

85 Churchill, "Reflections on the Cavalry Charge," Morning Post, October 7, 1898: 5.

86 Toye, 54; Russell, 227. It is worth noting that, owing to an old shoulder injury, Churchill exchanged his sabre for a thoroughly modern revolver.

87 Churchill, "Reflections on the Cavalry Charge," Morning Post, October 7, 1898: 5.

88 See Kucich, Imperial Masochism: British Fiction, Fantasy and Social Class.

89 Steevens, 266.

90 Henty. The Dash For Khartoum: A Tale of the Nile Expedition, 239-240.

91 Churchill, "The Entry into Omdurman," Morning Post, September 29, 1898: 6.

92 Churchill, "The Sudan Campaign," Morning Post, October 6, 1898: 5.

93 Churchill, "The Sudan Campaign," Morning Post, October 6, 1898: 5.

94 Churchill, "The Sudan Campaign," Morning Post, October 6, 1898: 5.

95 Bourke, Dismembering the Male: Men's Bodies, Britain and the Great War, 33.

96 Churchill, “The Sudan Campaign," Morning Post, October 6, 1898: 5.

97 Churchill, “The Sudan Campaign," Morning Post, October 6, 1898: 5.

98 Churchill, My Early Life, 79.

99 Pall Mall Gazette, "Occasional Notes," September 6, 1898: 2; The Times "Editorial," September 5, $1898: 7$.

100 Saturday Review, "The Battle of Omdurman," September 7, 1898: 383.

101 Blunt, "Modern War," 263.

102 Jenkins 40.

103 Ferguson, 272-73.

104 Winston Churchill, "The Entry into Omdurman," Morning Post, September 29, 1898: 6.

\section{Bibliography}

Alkon, Paul K. Winston Churchill's Visual Imagination. Lewisburg: Bucknell University Press, 
2006.

Barnes, John. The Beginnings of Cinema in England: 1894-1914. Vol. 4. 1992; Exeter: University of Exeter Press, 1996.

Blunt, Wilfred Scawen. “Modern War.” The Woman's Signal, October 27, 1898.

Bourke, Joanna. Dismembering the Male: Men's Bodies, Britain and the Great War. London:

Reaktion Books, 2009.

---. An Intimate History of Killing: Face-to-Face Killing in Twentieth Century Warfare. London: Granta, 2000.

Churchill, Winston. WSC to Lady Randolph, 10 August 1898. In Winston S. Churchill. Edited by Randolph Churchill. Vol. 1 Companion, Part 2. London: Heinemann, 1967: 961.

---. WSC to Captain Aylmer Haldane, 11 August 1898. In Winston S. Churchill. Edited by

Randolph Churchill. Vol. 1 Companion, Part 2. London: Heinemann, 1967: 964.

---. “The Soudan Campaign.” Morning Post, August 31, 1898.

---. “The War on the Nile.” Morning Post, September 2, 1898.

---. WSC to Colonel Ian Hamilton, 16 September 1898. In Winston S. Churchill. Edited by

Randolph Churchill. Vol. 1 Companion, Part 2. London: Heinemann, 1967: 976.

---. WSC to Lady Randolph, 17 September 1898. In Winston S. Churchill. Edited by

Randolph Churchill. Vol. 1 Companion, Part 2. London: Heinemann, 1967: 980-1.

---. “The War on the Nile.” Morning Post, September 24, 1898.

---. "The Battle of Omdurman.” Morning Post, September 29, 1898.

---. “The Entry into Omdurman.” Morning Post, September 29, 1898.

---. "The Sudan Campaign.” Morning Post, October 6, 1898.

---. "Reflections on the Cavalry Charge.” Morning Post, October 7, 1898.

---. “The Soudan Campaign.” Morning Post, October 13, 1898.

---. The River War. London: Longmans, 1899.

---. My Early Life: A Roving Commission. London: Thornton Butterworth, Ltd., 1930. 
[Churchill, Winston] “A Brave Lancer.” Trewman's Exeter Flying Post or Plymouth and Cornish Advertiser, October 15, 1898.

Dockter, Warren. "The Influence of a Poet: Wilfrid S. Blunt and the Churchills." Journal of Historical Biography 10 (Autumn 2011): 70-102.

Ferguson, Niall. Empire: How Britain Made the Modern World. London: Penguin, 2004.

Forbes, Algernon. "A War Correspondent's Reminiscences." The Nineteenth Century and After: A Monthly Review 30.175 (Sept. 1891): 414-429.

Fulton, Richard. “The Sudan Sensation of 1898." Victorian Periodicals Review 42:1 (Spring 2009): 38.

Habermas, Jurgen. The Structural Transformation of the Public Sphere: An Inquiry into a Category of Bourgeois Society. Translated by Thomas Burger. Cambridge: Polity, 1989.

Harvey, David. The Condition of Postmodernity: An Enquiry into the Origins of Cultural Change. Oxford: Basil Blackwell, 1989.

Haggard, Henry Rider. The Days of My Life. Vol. 1. London: Longmans, Green and Co., 1926. Henty, George Alfred. “The Life of a Special Correspondent.” The Boy's Own Paper, June 6, 1896. Illustrated London News, “London,” January 261884.

Jenkins, Roy. Churchill. Basingstoke: Macmillan, 2001.

Jeune, Susan, Baroness St Helier. Lady Jeune to Sir H. Kitchener, July 1898. In Winston S. Churchill. Edited by Randolph Churchill. Vol. 1 Companion, Part 2. London: Heinemann, 1967: 949.

Leisure Hour, "How the Newspaper is Made," January, 1883.

Kember, Joe and Simon Popple. Early Cinema: From Factory Gate to Dream Factory. London and New York: Wallflower, 2004.

Kipling, Rudyard. The Light That Failed. London and New York: Macmillan and Co., 1891. Kucich, John. Imperial Masochism: British Fiction, Fantasy and Social Class. Princeton and Oxford: Princeton University Press, 2007. 
Lee, Alan J. The Origins of the Popular Press in England, 1855-1914. London: Croom Helm, 1976.

MacKenzie, John M., ed. Imperialism and Popular Culture. Manchester and New York: Manchester University Press, 1986.

Marinetti, Filippo Tommaso, quoted in Walter Benjamin. Illuminations. Edited by Hannah Arendt. Translated by Harry Zorn. London: Pimlico, 1999.

Markovits, Stefanie. "Rushing Into Print: 'Participatory Journalism' During the Crimean War." Victorian Studies 50:4 (Summer 2008): 559-586.

Morning Post, "London," August 19, 1898.

Morning Post, “The Romance of Khartoum," September 5, 1898.

Nietzsche, Friedrich. Twilight of the Idols and The Anti-Christ. Edited by Michael Tanner. Translated by R.J. Hollingdale. London: Penguin, 2003.

Pakenham, Thomas. The Scramble for Africa. St. Ives: Abacus, 2003.

Pall Mall Gazette, “Occasional Notes,” September 6, 1898.

Read, Donald. England, 1868-1914: The Age of Urban Democracy. London and New York: Longman, 1979.

---. The Power of News: The History of Reuters, 1848-1989. Oxford and New York: Oxford University Press, 1992.

Russell, Douglas S. Winston Churchill, Soldier: The Military Life of a Gentleman at War. London: Brassey’s, 2005.

Saturday Review, “The Battle of Omdurman,” September 7, 1898.

Searle, G.R. A New England? Peace and War, 1886-1918. Oxford: Clarendon Press, 2004.

Springhall, John O. “'Up Guards and At them!': British imperialism and popular art, 1880-1914.” In Imperialism and Popular Culture, edited by John M MacKenzie, 49-72. Manchester and New York: Manchester University Press, 1986.

Stead, William Thomas. “Government by Journalism.” Contemporary Review 49 (May 1886): 65354. 
Steevens, George Warrington. With Kitchener to Khartoum. 1898; London: Darf, 1987.

The Times, "Editorial," September 5, 1898.

The Times, “The Sudan Campaign (Through Reuter's Agency),” August 1, 1898.

Toye, Richard. Churchill's Empire: The World That Made Him and the World He Made.

Basingstoke and Oxford: Pan Books, 2010.

Weidhorn, Manfred. Sword and Pen: A Survey of the Writings of Winston Churchill. Albuquerque: University of New Mexico Press, 1974.

Wilson, Trevor. The Myriad Faces of War: Britain and the Great War, 1914-1918. Cambridge, Polity Press, 1986.

Woods, Frederick, ed. Winston S. Churchill: War Correspondent, 1895-1900. London: Brasseys, 1992.

---. Artillery of Words: The Writings of Sir Winston Churchill. London: Leo Cooper, 1992. 